\title{
DESAIN KEMASAN JAMUR TIRAM CRISPY
}

\author{
Ahmad Thibtum Fairuzy ${ }^{1)}$, Arief Aji Kurniawan ${ }^{2)}$, Iqbal Maulana Salvais ${ }^{3)}$ \\ Program Studi Desain Komunikasi Visual, \\ Fakultas Bahasa dan Seni, Universitas Indraprasta PGRI \\ Jl. Nangka No. 58 C, Tanjung Barat, Jakarta Selatan, 12530, Indonesia \\ fairuzy.coz@gmail.com
}

\begin{abstract}
Abstrak
Jamur tiram crispy adalah camilan yang banyak disenangi masyarakat dari berbagai kalangan. Bukan hanya lembut dan nikmat saat dimakan, tetapi juga sangat bergizi dan bermanfaat bagi kesehatan. Jamur tiram crispy dikenal sebagai camilan karena bobotnya yang pas untuk menjadi makanan ringan. Agar masyarakat Indonesia makin tertarik mengonsumsi dan mengenal jamur tiram crispy, kemasan pemasaran jamur tiram crispy haruslah diperbaharui agar sesuai dengan selera dan trend masa kini. Tujuan penelitian ini adalah untuk medesain kemasan jamur tiram crispy. Metode penelitian yang digunakan adalah kualitatif dengan dengan pendekatan kepustakaan. Hasil dari penelitian ini adalah desain kemasan jamur tiram dengan visualisasi dalam bentuk desain kemasan pouch. Warna yang digunakan merah, maroon, putih, abu-abu, cream, kuning tua, cokelat, dan hitam. Logo gram yang akan digunakan untuk icon logo "SHAFA" jamur crispy adalah seorang karakter jamur dengan pakaian ala cheff professional. Logo type yang digunakan, yaitu font Hobo std dan font Keep Calm. Objek pendukung digunakan agar logo terlihat lebih menarik, objek tersebut adalah lingkaran bewarna kuning yang ditujukan agar logo tersebut terlihat lebih tegas dan jelas, juga lebih menarik mata dengan warnanya yang cerah.
\end{abstract}

Kata Kunci: jamur, tiram, crispy, camilan, trend

\begin{abstract}
The Crispy oyster mushrooms are a snack that many people love from various circles. Not only soft and delicious when eaten, but also very nutritious and beneficial for health. Crispy oyster Mushroom is known as a snack because its weight is fitting to be a snack. For Indonesian people to be more interested to consume and to know the crispy oyster mushroom, the marketing packaging of crispy oyster mushroom should be updated to match the tastes and trends of the present. The purpose of this research is to design crispy oyster mushroom packaging. The method of research used is qualitative with a library approach. The result of this research is the packaging design of oyster mushroom with visualization in the form of packaging design pouch. The colors used are red, maroon, white, grey, cream, dark yellow, brown, and black. The Gram logo to be used for the icon logo "Shafa" crispy mushroom is a mushroom character with a professional best-ala outfit. The type Logo used is the Hobo std font and the Keep Calm font. The supporting object is used for the logo to look more attractive, the object is a yellow circle aimed to make the logo look more assertive and clear, also more interesting eye with a bright color.
\end{abstract}

Keywords: mushrooms, oysters, crispy, snack, trend

Correspondence author: Ahmad Thibtum Fairuzy, fairuzy.coz@gmail.com, Jakarta Selatan, and Indonesia

(i) (3)

This work is licensed under a $C C-B Y-N C$ 


\section{PENDAHULUAN}

Budi daya jamur sangat cocok untuk daerah beriklim tropis seperti Indonesia. Investasi yang dibutuhkan untuk memulai usaha budi daya jamur cukup murah dan bisa dilakukan bertahap. Bagian tersulit dalam budi daya jamur adalah membuat baglog, media tanam yang telah diinokulaikan dengan bibit jamur.

Dari hasil penelitian, rata-rata jamur mengandung 19-35 persen protein. Dibanding beras (7,38 persen) dan gandum (13,2 persen), jamur berkadar protein lebih tinggi. Asam amino esensial yang terdapat pada jamur yaitu sekitar sembilan jenis dari 20 asam amino yang dikenal. Para peneliti dari Ujagar Group (India) menyampaikan, bahwa jamur tiram memiliki nilai nutrisi yang sangat bagus dengan alasan: 100 persen sayuran dan bersih, mengandung protein tinggi dan kaya vitamin-mineral, rendah karbohidrat, lemak dan kalori, bagus untuk liver, pasien diabetes, dan menurunkan berat badan, berserat tinggi membantu pencernaan, antiviral dan antikanker, mudah memasaknya dan mudah dicerna, dan jamur tiram merupakan jamur yang paling enak rasanya dibanding jamur pangan lainnya (Adianto dan Wulandari, 2015).

Jamur adalah kuliner yang nikmat, banyak rumah makan yang menggunakan jamur sebagai bahan pengganti untuk daging. Terutama bagi mereka yang menghindari makanan olahan seperti daging, jamur sangat cocok sebagai pengganti. Dengan pengedukasian seperti ini, masyarakat mempunyai pandangan bahwa jamur merupakan camilan yang sehat.

Salah satu makanan olahan jamur yang paling digemari konsumen adalah jamur tiram crispy. Masakan berbahan dasar jamur tiram ini mulai banyak disukai para penikmat kuliner, mungkin karena rasanya yang gurih dan teksturnya yang renyah membuat sensasi tersendiri bagi lidah. Apalagi ditunjang dengan keunggulan dari bahan bakunya yaitu jamur tiram yang tanpa kolesterol dan mengandung berbagai macam manfaat bagi kesehatan (berbisnisjamur, 2015).

Bisnis jamur crispy adalah bisnis kuliner, semacam keripik dari jamur tiram putih. Proses membuat jamur crispy sebenarnya juga sangat sederhana, sama saja dengan membuat ayam goreng crispy, sedangkan untuk membuat kripik jamur, hanya menambahkan proses spinner dan menggorengnya lebih lama saja (karena dimasak sampai kering). Usaha ini masih cukup potensial, memang karena harganya masih cukup tinggi, segmentasi pemasarannya masih cukup terbatas. Ditambah lagi modal untuk memulai usaha ini tidak terlalu besar sehingga usaha ini sesuai dengan kantong mahasiswa.

Jamur crispy banyak disukai para penikmat kuliner. Apalagi ditunjang dengan keunggulan dari bahan bakunya yaitu jamur tiram dan jamur kuping yang tanpa kolesterol dan mengandung berbagai macam manfaat bagi kesehatan. Peminat jamur crispy ini sebagaian besar adalah para remaja sehingga dengan mudah untuk memasarkan produk ini (Adianto dan Wulandari, 2015).

Saat ini jamur crispy yang beredar dikemas dengan desain seadanya. Hal itu membuat kurang menariknya tampilan dari makanan tersebut. Oleh sebab itu, pada penelitian ini akan medesain kemasan jamur tiram crispy, agar menarik untuk dilihat selain kandungan gizinya yang tinggi. Perancangan desain kemasan jamur tiram crispy akan divisualisasikan dalam bentuk desain kemasan pouch, karena menurut hasil penelitian dibanyak restoran cepat saji yang berada di Jakarta menggunakan kemasan pouch untuk makanan-makanan ringan, seperti kentang. Tentunya ini memudahkan para konsumen untuk mengonsumsi produk dan juga simpel serta modern seperti yang disukai kebanyakan masyarakat Indonesia saat ini.

\section{METODE PENELITIAN}

Metode penelitian ini menggunakan metode kualitatif, yaitu studi pustaka dengan pengumpulan data literatur dari jurnal artikel ilmiah, skripsi, dan buku. Beberapa di antaranya juga diambil dari artikel yang di-posting di web. Metode penelitian kualitatif adalah sebuah metode riset yang sifatnya deskriptif, menggunakan analisis, mengacu pada data, memanfaatkan teori yang ada sebagai bahan pendukung, serta menghasilkan suatu teori. Jadi, setiap kutipan yang diambil bersifat subjektif dari sudut pandang partisipan secara deskriptif sehingga hasilnya tidak dapat digeneralisasikan. 


\section{HASIL DAN PEMBAHASAN}

Persaingan dalam bidang pemasaran suatu produk di antara sesama produsen kian waktu tidak dapat dihindari lagi. Setiap perusahaan berlomba-lomba untuk memasarkan produknya agar laku dijual kepada konsumen. Beberapa cara diterapkan dalam memasarkan produknya agar minat beli konsumen menjadi tinggi dan produk terjual, salah satu strategi pemasaran yang dapat dilakukan oleh produsen dalam meningkatkan atau mempengaruhi minat beli konsumen adalah dengan mendesain kemasan yang dapat menarik hati konsumen sehingga dapat meningkatkan minat beli. Minat beli merupakan keinginan untuk membeli yang timbul setelah konsumen merasa tertarik dan ingin memakai produk yang dilihatnya. Jadi, desain kemasan pada suatu produk dapat memiliki pengaruh penting terhadap minat beli konsumen (XDESAIN, 2018). Pendapat lain juga menegaskan bahwa "Teknologi telah membuat kemasan berubah fungsi, dulu orang mengatakan kemasan melindungi apa yang dijual sedangkan sekarang kemasan menjual apa yang dilindungi" (Cenadi \& Christine, 2000).

Persaingan yang kompetitif dalam bisnis akan menciptakan customer sendiri-sendiri antarproduk karena persaingan itu akan membuat konsumen menjadi yakin dalam memilih dan membeli produk terhadap merek tertentu melalui desain kemasan yang baik. Untuk menyakinkan konsumen tersebut agar dapat melakukan pembelian diperlukan suatu strategi desain kemasan yang baik dan pemasaran produk yang baik pula. Salah satu tujuannya yaitu merebut pasar dan menarik konsumen untuk membeli produknya melalui desain kemasan (packaging desain) semenarik mungkin sehingga dapat diminati oleh konsumen (Rosandi, 2014).

Konsumen dapat meningkatkan citra perusahaan dan merek (company and brand image) yaitu semakin bagus kemasan tersebut maka produk tersebut dapat mendapatkan keyakinan konsumen mengenai perusahaan/mereknya dan dapat pula dijadikan sebagai peluang inovasi (inovation opportunity). Inovasi desain kemasan yang baik harus dapat memenuhi keinginan dan kemampuan perusahaan serta didesain sesuai dengan teknologi yang tersedia di perusahaan tersebut. Dengan demikian perusahaan berusaha untuk merubah desain kemasan produk yang ada, memperbaiki desain kemasan yang ada, menambah kemasan yang baru, atau mengambil tindakan yang lain melalui beberapa strategi pengembangan kemasan yang dapat mempengaruhi kebijakan dalam menentukan kemasan produk (Rosandi, 2014)

Kemasan adalah hal pertama yang dilihat konsumen sebelum produk itu sendiri, jasa desain kemasan menarik dan baik akan mempengaruhi minat beli konsumen, hal ini dipengaruhi oleh faktor berikut ini: Faktor pertama, jasa desain kemasan yang menarik adalah citra diri dari produk yang dibuat, misalkan sebuah produk makanan dikemas hanya menggunakan plastik bening akan berbeda dengan makanan yang dikemas dengan stereofoam. Begitu pula dengan desain kemasan, desain kemasan yang menarik dengan menampilkan logo, warna, motif tertentu akan menimbulkan pengaruh besar pada minat beli konsumen. Contoh lain adalah jika anda membeli makanan di restoran cepat saji dengan dibungkus menggunakan box makanan bermotif/corak akan terlihat lebih menarik dibanding dengan makanan sejenis yang dijajakan di kaki lima, hal ini akan membuat minat beli konsumen lebih tinggi dibanding dengan kemasan biasa (XDESAIN, 2018).

Kedua, faktor warna desain kemasan yang dikombinasikan satu sama lain akan menjadi pengaruh utama dalam perilaku konsumen untuk membeli produk anda. Jika sebuah produk memiliki warna yang bagus akan meningkatkan daya beli konsumen dalam hal memilih produk dengan warna yang bagus atau enak dipandang. Dalam dunia desain, warna adalah kunci utama bagi elemen desain karena memberi kesan jelas terhadap produk. Warna yang tepat akan memengaruhi baik buruknya kemasan sehingga berpengaruh terhadap minat pembeli akan produk anda (XDESAIN, 2018).

Faktor ketiga adalah adanya elemen lain dalam desain kemasan yang dimasukan, seperti bentuk kemasan, gambar pendukung, informasi produk, desain pembungkus, jenis huruf, dan elemen pendukung lainnya. Apabila elemen-elemen ini dikombinasikan dengan warna dan desain utama yang menarik dan dilakukan dengan tepat tentu akan meningkatkan minat beli konsumen. 
Mata konsumen pada dasarnya akan tertuju pada kemasan terlebih dahulu, kemudian menganalisis isi produk (XDESAIN, 2018).

Oleh karena itu, dari beberapa faktor di atas dapat disimpulkan bahwasannya kemasan sangat dibutuhkan pula untuk penjualan cemilan khas Nusantara seperti jamur tiram crispy agar menarik minat pembeli dan menciptakan citra bagi produk jamur tiram crispy itu sendiri.

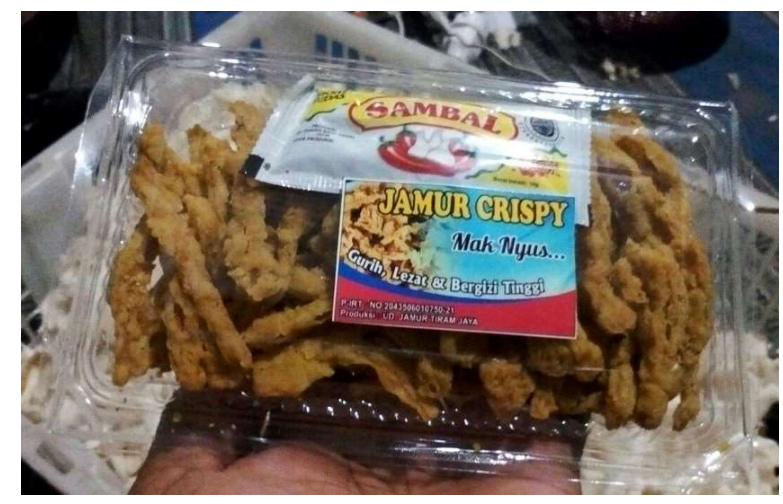

Gambar 1. Contoh Kemasan Jamur Tiram Crispy Sumber: bukalapak.com

\section{Proses Perancangan Desain Kemasan Jamur Tiram Crispy}

A. Tahap Eksplorasi

Eksplorasi dilakukan di restoran-restoran cepat saji yang umum di Indonesia seperti KFC, MCD, CFC, dan lainnya. Eksplorasi dilakukan dengan tujuan membandingkan minat beli masyarakat Indonesia terhadap desain kemasan tradisional pedagang kaki lima dan desain kemasan modern dari restoran cepat saji.

B. Tahap Improvisasi

Bentuk desain kemasan pouch yang diambil sebagai dasar dari desain kemasan jamur tiram crispy tersebut cepat diterima masyarakat Indonesia khususnya masyarakat perkotaan ini. Acuan icon desain kemasan jamur tiram crispy adalah icon jamur penguat di game super mario yang pastinya hampir seluruh masyarakat Indonesia mengenal icon ini, dan icon cheff untuk penggambaran profesionalitas dari cemilan jamur tiram crispy.

C. Tahap Desain Logo/Brand Kemasan

Sebelum mendesain secara visual, diperlukan pembentukan konsep logo secara tertulis. Beberapa hal yang perlu diperhatikan adalah "Deskripsi Logo beserta gambar visualnya "di mana berbagai hal yang menyangkut logo tersebut dijabarkan lewat latar belakang seperti nama brand, pickcolor, konsep icon untuk logo gram, konsep logo type, dan gaya visual. Spesifikasi visual logo/brand yang akan digunakan adalah sebagai berikut:

1. Nama Brand: "SHAFA" Jamur Crispy

Kata "SHAFA" muncul berasal dari nama salah satu pemilik usaha jamur tiram crispy. 


\section{Pickcolor}
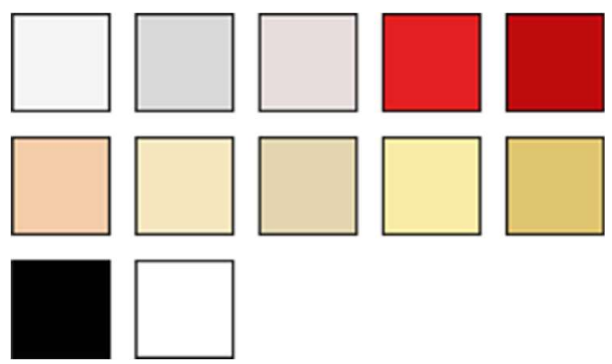

Warna di atas adalah rancangan warna yang akan digunakan untuk logo "SHAFA" Jamur Crispy. Terinspirasi dari warna icon jamur penguat karakter pada game super mario. Di sana terdapat warna merah, maroon, putih, abu-abu, cream, kuning tua, cokelat, dan hitam. Warna-warna tersebut dimaksudkan menggambarkan dari kekuatan dan semangat diwakili oleh warna merah, kebersihan diwakili oleh warna putih, ketegasan diwakili oleh warna hitam, warna cream dan abu-abu sebagai perwakilan dari kepolosan serta modern atau kekinian. Berikut merupakan contoh inspirasi icon:

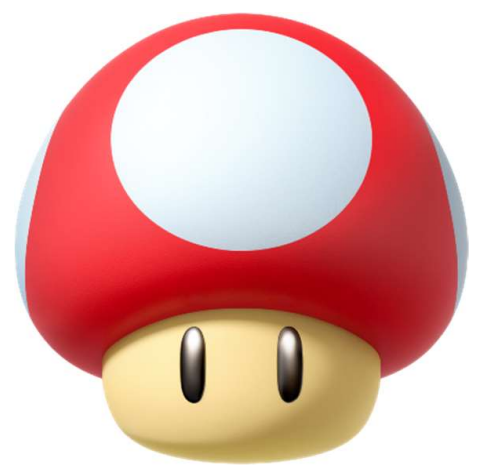

Gambar 2. Mushroom Super Mario

Sumber : www.mariowiki.com

3. Logo Gram: logo gram yang akan digunakan untuk icon logo "SHAFA" Jamur Crispy adalah seorang karakter jamur dengan pakaian ala cheff professional. Karakter jamur ini terinspirasi dari karakter jamur penguat pada game super mario dengan alasan penggambaran visual dengan filosofi yang sama dengan karakter super mario tersebut yaitu jamur crispy sebagai penguat badan. Sementara penggambaran pakaian cheff professional membawa filosofi penggambaran visual bahwa brand "SHAFA" adalah produsen makanan ringan yang professional. 


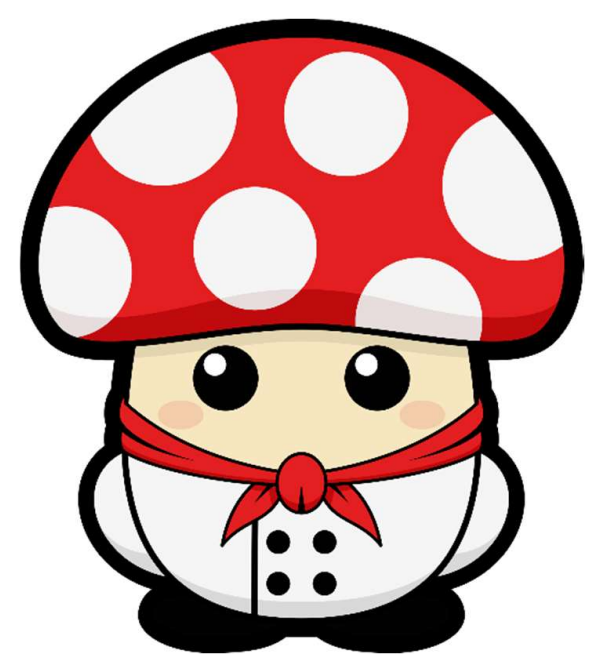

Gambar 3. Logo Gram SHAFA Jamur Tiram Cispy. Sumber: Dokumen Pribadi

4. Logo Type: untuk logo type yang digunakan "SHAFA" Jamur Crispy sendiri menggunakan font Hobo std untuk type "SHAFA" dimaksudkan penegasan branding produknya dan penegasan ini juga ditujukan untuk dominasi dan positioning brand, agar ketika konsumen melihat produk jamur crispy hal yang pertama diingat adalah "SHAFA". Untuk type Jamur Crispy sendiri menggunakan font Keep Calm, font yang cocok digunakan sebagai pendukung brand utama atau logo type yang utamanya.

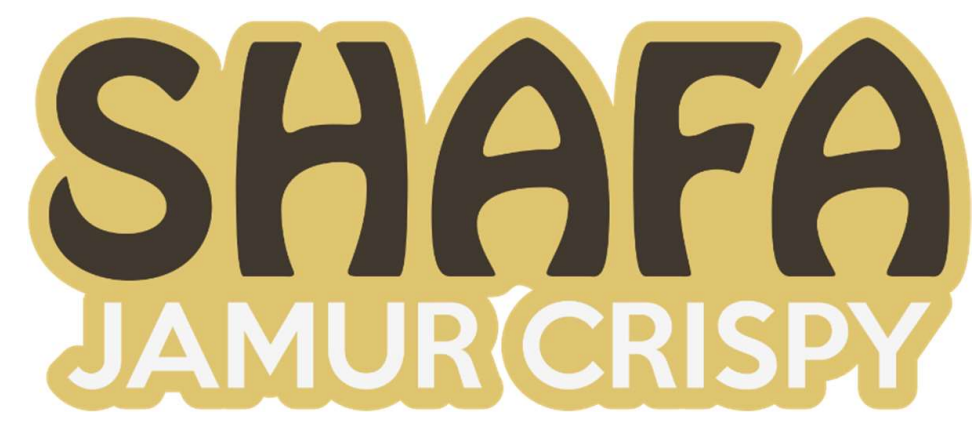

Gambar 4. Logo Type SHAFA Jamur Tiram Cispy Sumber: Dokumen Pribadi

5. Objek pendukung : logo "SHAFA" Jamur Crispy memiliki satu objek pendukung agar logo terlihat lebih menarik, objek tersebut adalah lingkaran bewarna kuning yang ditujukan agar logo tersebut terlihat lebih tegas dan jelas, juga lebih menarik mata dengan warnanya yang cerah. 


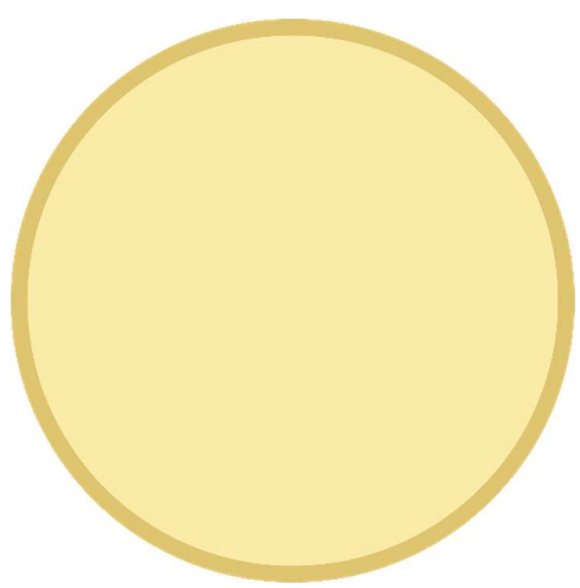

Gambar 5. Objek Pendukung Logo SHAFA Jamur Tiram Cispy Sumber: Dokumen Pribadi

Berdasarkan spesifikasi karakter tersebut, maka jadilah logo "SHAFA" Jamur Crispy yang modern dan kekinian, seperti berikut:

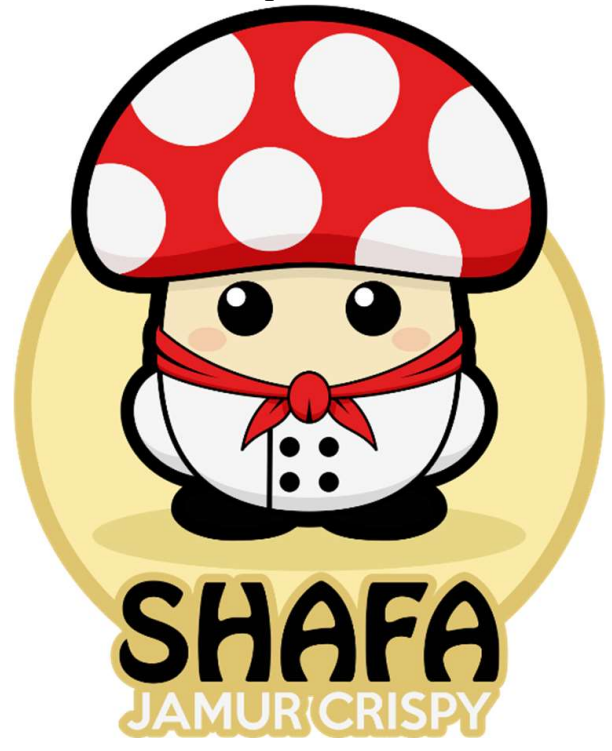

Gambar 6. Logo SHAFA Jamur Tiram Cispy Sumber: Dokumen Pribadi

D. Tahap Desain Kemasan Produk

Desain kemasan produk yang paling cocok untuk jamur crispy milik SHAFA adalah desain kemasan pouch, karena simple, kekinian, mudah dibawa, dan mudah digunakan. Kemasan sendiri memiliki konsep warna yang tidak jauh beda dengan brandnya, dengan background siluet jamur tiram agar nuansa dari rasa jamur tiram itu tervisualisasikan lewat background dari desain kemasannya.

Berikutnya terdapat logo/brand SHAFA diletakkan ditengah sebagai dominasi dari desain kemasan, diletakkan ditengah agar mata terarah dan terfokus kepada logo, jadi positioning dari SHAFA akan masuk dikemasan tersebut "ingat jamur tiram crispy, ingat SHAFA". Slogan produk juga diletakkan di tengah sebagai objek kedua setelah logo/brand 
yang menjadi dominasi, jadi setelah mata terarah kepada logo/brand selanjutnya mata akan mengarah kepada slogan produk. Di bagian depan kemasan produk juga terdapat list dari rasa produk olahan jamur tiram SHAFA, diletakkan di bawah pojok kanan kemasan agar tidak membuat mata bingung karena bertabrakan dengan dominasi kemasan yaitu logo dan slogan produk. Tidak lupa juga mencantumkan logo halal sebagai legalitas kehalalan produk jamur tiram SHAFA yang dijamin langsung oleh Majelis Ulama Indonesia, beserta berat bersih produk di bagian bawah tengah sebagai pelengkap dari kelengkapan Standar Nasional kemasan Indonesia. Di belakang kemasan berisi tentang komposisi dan berbagai kelengkapan Standar Nasional kemasan, dibuat sesimpel mungkin agar terlihat tetap menarik dan tidak membosankan. Pemilihan warna sendiri menggunakan warna-warna dari jamur tiram, agar menggambarkan jelas bahwa kemasan pouch SHAFA adalah kemasan dari produk olahan jamur tiram asli. Berikut rancangan kemasan pouch SHAFA Jamur Crispy:

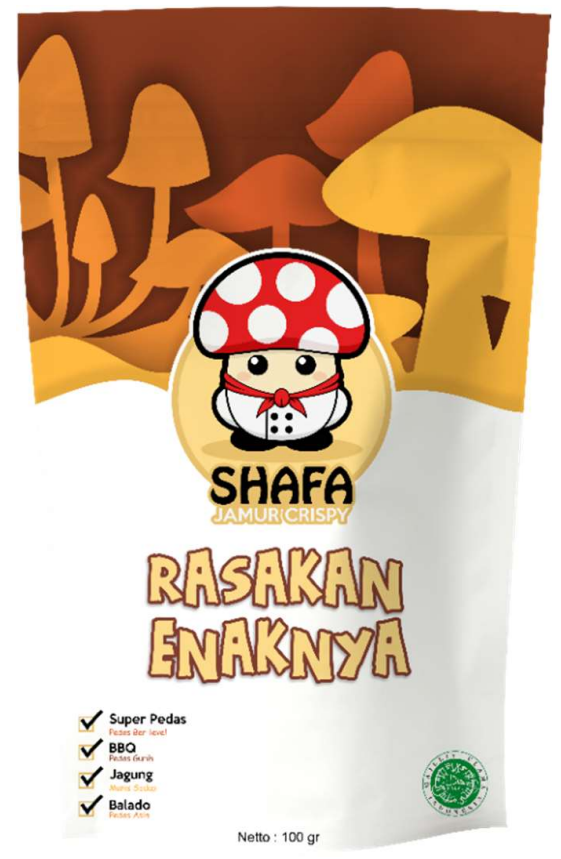

Gambar 7. Kemasan Pouch Bagian Depan Sumber: Dokumen Pribadi

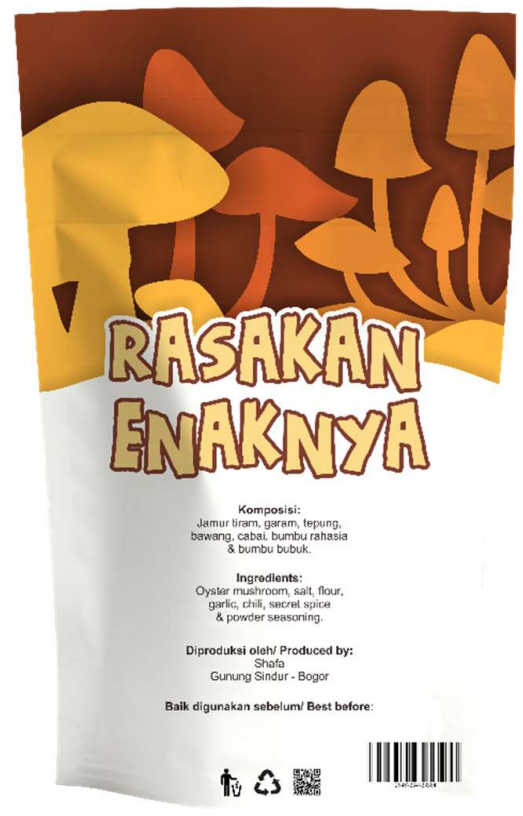

Gambar 8. Kemasan Pouch Bagian Belakang Sumber: Dokumen Pribadi

\section{SIMPULAN}

Desain kemasan untuk usaha jamur tiram crispy sangat mempengaruhi minat beli para konsumen, bukan hanya berdampak meningkatnya kualitas produk, tetapi desain kemasan juga bisa berdampak pada proses periklanan dan promosi produk. Desain kemasan jamur crispy "SHAFA" juga merupakan salah satu terobosan baru untuk cemilan atau makanan ringan khas Nusantara ini. Diharapkan nantinya akan mulai banyak bermunculan cemilan khas Nusantara dengan desain kemasan produk yang menarik agar meningkatkan minat beli masyarakat serta meningkatkan popularitas cemilan Nusantara dikancah nasional dan internasional. Hasil desain kemasan jamur tiram dengan visualisasi dalam bentuk desain kemasan pouch. Warna yang digunakan merah, maroon, putih, abu-abu, cream, kuning tua, cokelat, dan hitam. Logo gram yang akan digunakan untuk icon logo "SHAFA" jamur crispy adalah seorang karakter jamur dengan pakaian ala cheff professional. Logo type yang digunakan, yaitu font Hobo std dan font Keep Calm. Objek pendukung digunakan agar logo terlihat lebih menarik, objek tersebut adalah 
lingkaran bewarna kuning yang ditujukan agar logo tersebut terlihat lebih tegas dan jelas, juga lebih menarik mata dengan warnanya yang cerah.

\section{DAFTAR PUSTAKA}

Adianto, M., Rahayu N, S., \& Wulandari, W. (2015). Jamur crispy nam kho. Surakarta.

berbisnisjamur. (2015). Jamur tiram crispy. Retrieved June 26, 2019, from https://berbisnisjamur.com/jamur-tiram-crispy/

Cenadi, \& Christine, S. (2000). Peranan desain kemasan dalam dunia pemasaran. Jurnal Nirmala, 2(1), 92-103.

Rosandi, S. (2014). Pengaruh citra merek dan desain kemasan terhadap minat beli konsumen pada produk susu ultra. Universitas Negeri Surabaya.

XDESAIN. (2018). Pengaruh desain kemasan terhadap minat beli konsumen. Retrieved July 3, 2019, from https://xdesain.com/pengaruh-desain-kemasan-terhadap-minat-belikonsumen/ 